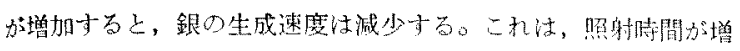

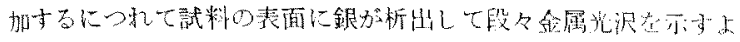

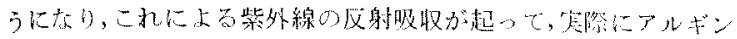

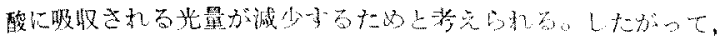

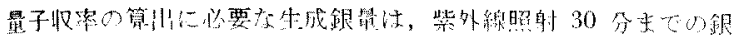

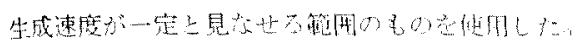

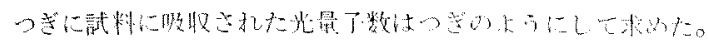

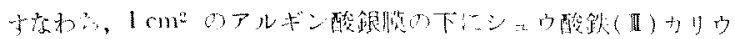

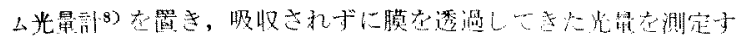

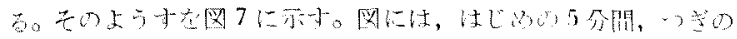

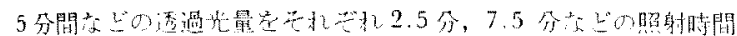

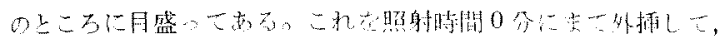

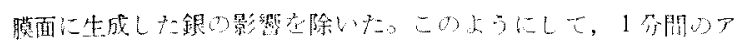

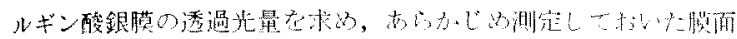
の照射強度加らこれを差し引くこにに上って，アルギン酸鍶膜心 吸收された光量子数を求めた。したがって，アルギン酸銀膜をれ 自身による反射は考虑されていない。

このようにして算出した量子収率は 0.015 でった。Jacobs お

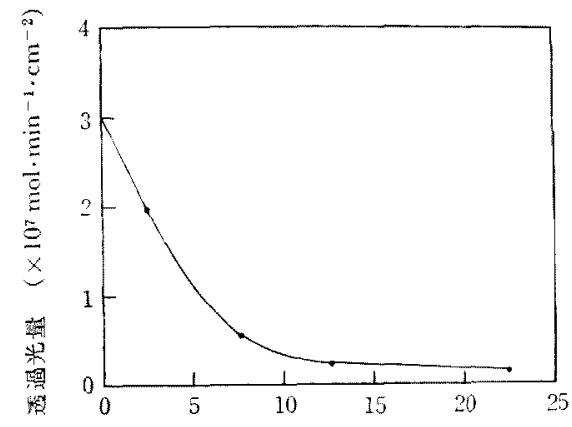

照射時䦩 (min)

図7アルギン酸銀䑏の紫外線照射時閾に上る 诱週光星の罗化

8) C. A. Parker, Proe. Roy. Soc. 220 A, 104(1953); 235 A, $518(1956)$
よび Tompkins らのは，アシ化バリウム結晶の紫外線による光分

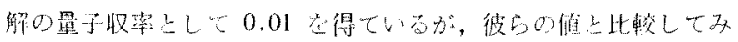
ても，アルギン酸銀の 0.015 法固体の光分解の黑子収率上して

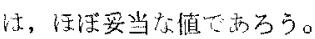

\section{4 光分解機構}

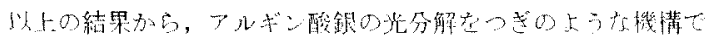

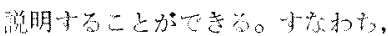

$$
\begin{aligned}
& \mathrm{RCOOAg}+\boldsymbol{h} \nu \longrightarrow \mathrm{RCOO}+\mathrm{Ag} \\
& \mathrm{RCOO}+\mathrm{H}_{2} \mathrm{O} \longrightarrow \mathrm{RCOOH}+\cdot \mathrm{OH}
\end{aligned}
$$

ここてRはアルギン特のカルボキシル基展除いた部分てある。

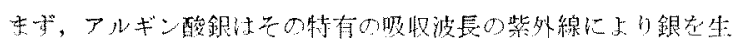

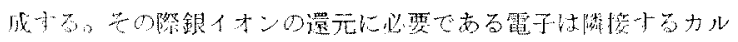

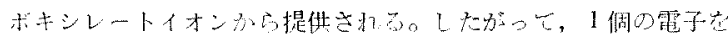

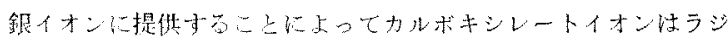

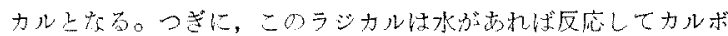

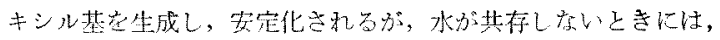

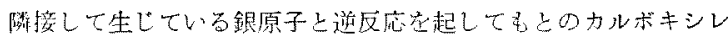

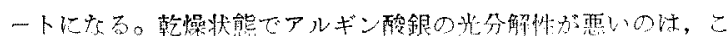

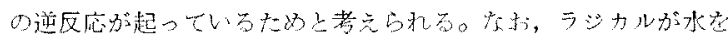

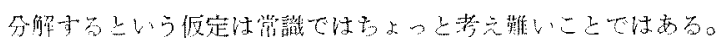

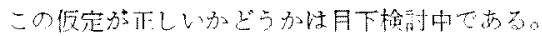

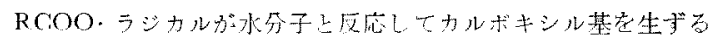

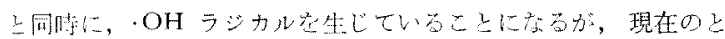

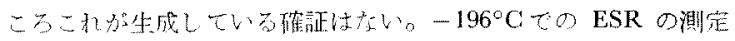

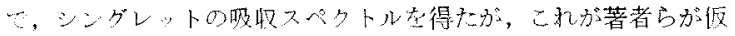

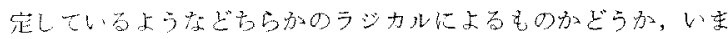
のとこ名㯕定で等い。

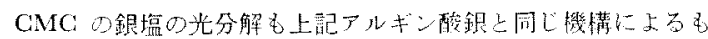
○と推定き阮引。

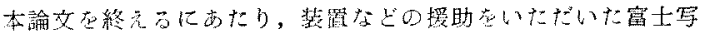
筫つイルム株式会社に感謝の慧党表守。

(1964 年4月，日本化学会第 17 科金笔表)

9) P.W. M. Jacobs, F. C. Tompkins, Proc. Roy. Sac. 215 A, 254(1952).

\title{
アルギン酸銀膜の光分解生成物の電気伝導性
}

(㫿和 40 年 7 月 10 日受理)
田村幹婎・羽

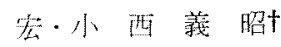

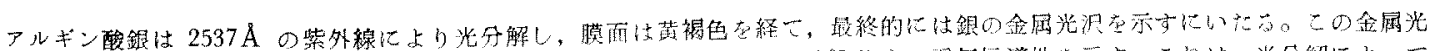

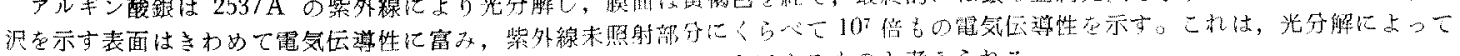

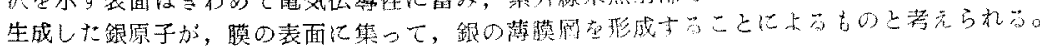

\section{1 緒 窝}

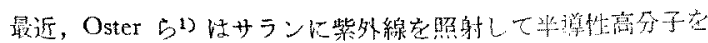

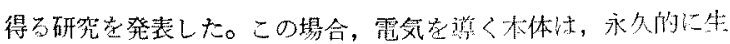

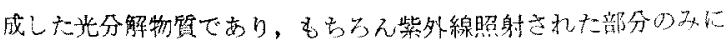

$\dagger$ Mikio TAMURA, Hiroshi HADA, Yoshiaki KONISHI 倞推大学工桇

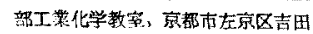

1) G. Oster, G. K. Oster, M. Kryszewsky, Natuze 191, 161(1961).

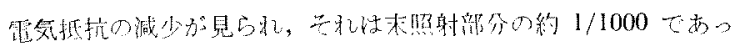
to

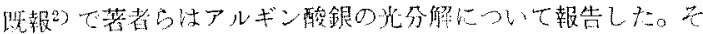

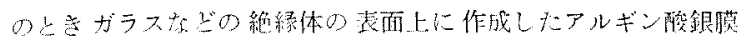

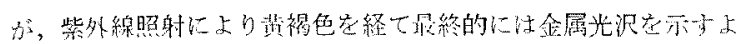

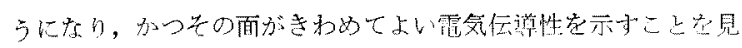
2)小四, 鹏, 男村, 白化 86, 1132(1965). 


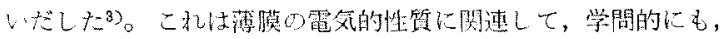

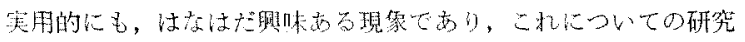

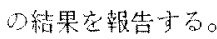

\section{2 実験}

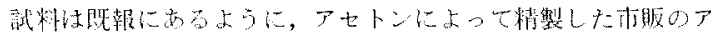

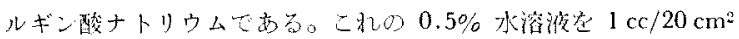

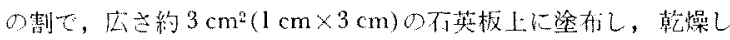

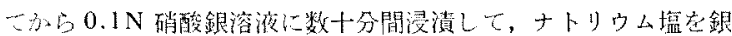

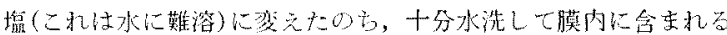

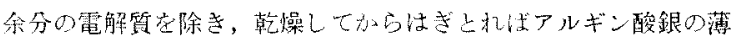

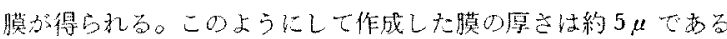

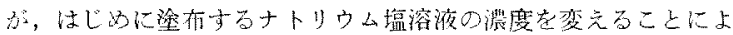

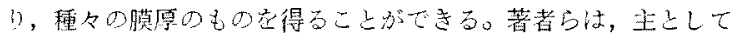
膜曆 $5 \mu$ の日の用いて実駼した。 $5 \mu$ 以下の膜厚では，薄すす

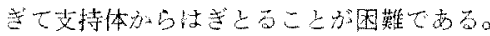

紫外線照射に恃，東芝GT-1511NB 型殺菌灯定使用した。この 殺菏灯は，てのエネルギ一のほとえどが $2537 \AA$ の紫外線であ る。アルギン酸銀膜がこの波長領域に㧅、て光分解するここは，

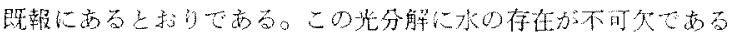

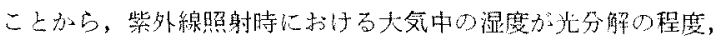

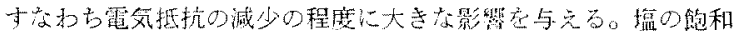

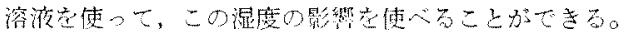

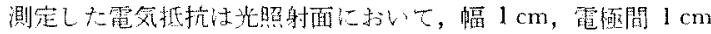

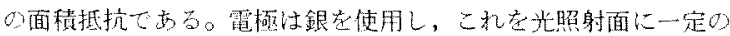
强さて押しつけることかてさるようにした。

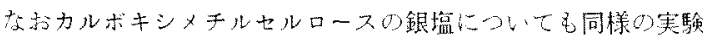

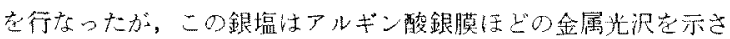
な゙，したがって電気抵抗もそれはど減少しない。

\section{3 結果および考祭}

アルギン酸銀膜の照射時間による電気抵抗の变化を图1に示し た。この図恃，厚さ $5 \mu$ のアルギン酸銀落を用いて，大気中，湿 度 70\%て紫外線照射したものである。紫外線未照射のアルギン

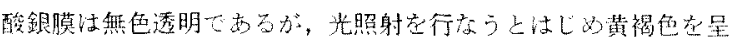

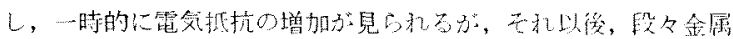

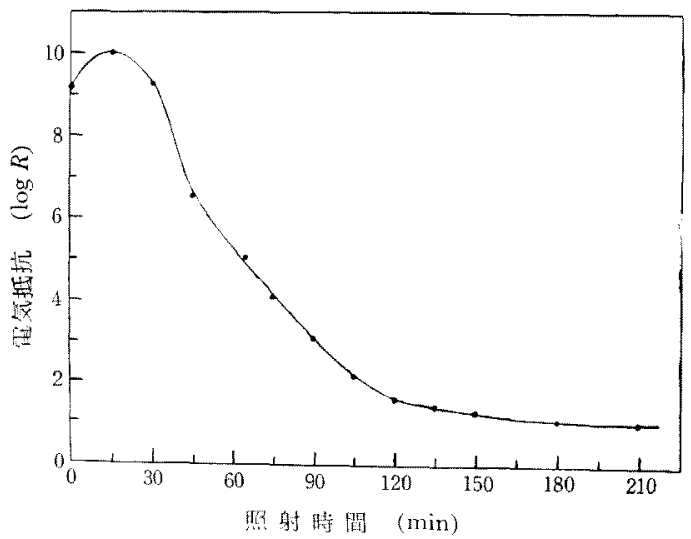

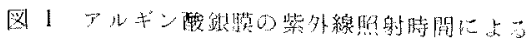

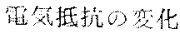

3) 羽田, 小酉, 田村，物性 5,738(1964)

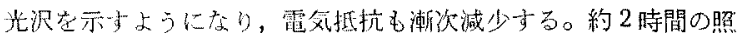
射後では膜面は完全な鏡えなり，電気抵抗は未照射のときよりる $10^{7}$ 愔も娍少して的 $10^{2} \Omega$ にな。これ以後，光照射索つうけて

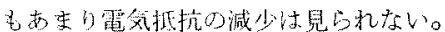

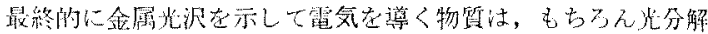
生成物の鍶で古。このことは，前に報告したように，光分解生 成物の化学的性筫によって明らかにされているが，また金属光沢 在持つ面のX線回折の測定\%ら，金属銀の乙机上一致子る格子定 数名得られたことから，金属状委だてれにきかわて近い状態の 銀(コロイド銀粒子の密なる策合)ですることは間䔔いない。

紫外線照射初期に扮ける電気抵抗の增加については，つぎの二

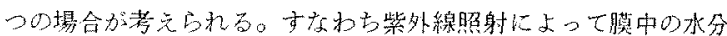
加光分解に消費され，この水分の減少の力が，初期の銀析出上り も電気抵抗に大きく影唧すると考无る場合上，第二は，格子間銀 イオンが光分解に消費されるためにイオン伝導度が咸少し，この

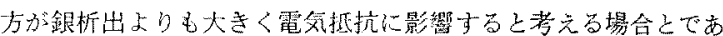
る。いまの上こるどちら上も決定でないが，おをらくこの二つ の場合のいず机多関係しているという場合の方がよりありそう なことくある。

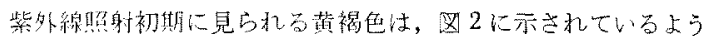
に系の可視部の吸収スペクトルの位置が

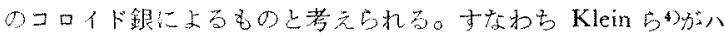
ロゲン化銀乳剂壳物理現像して得たここるのゼラチン中における コロイド銀椟子についての研究に上れば，こ机ら粒子の散乱によ る吸收带が同じ上らに可視部にあって，粒子の大ききが增大寸る につ机て，Zの極大吸収波長が長波長領域以移動する。アルギン 酸銀の紫外線照射に上って得的九万着色は，乙の極大吸収波長肪 $425 \mathrm{~m} \mu$ に相当し，この吸収位置は図 2 亿示さ机ているように， 紫外線照射安つうけても移動しない。

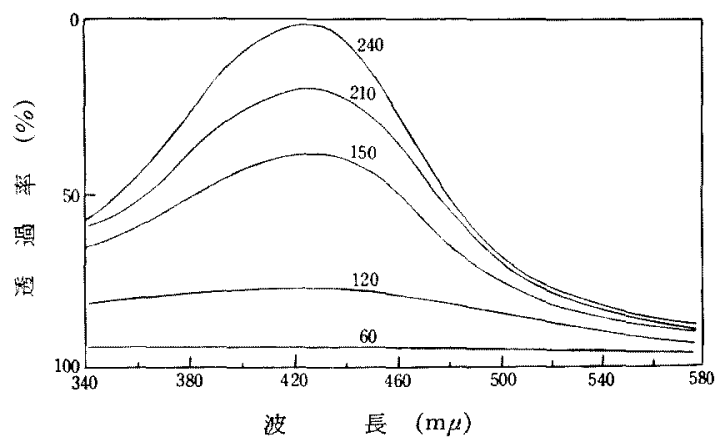

図中の数字は照射㭙間( $\sec$ )示す。

图2 アルギン酸銀の紫外線照射後の四収スペタトル

したがって Klein らの結果定採用寸れば，アルギン酸銀の埸 合法紫外線照射に上って生成した銀原子が集合して $20 \mathrm{~m} \mu$ 以下 の大きさのコロイド銀粒子壳形成するが，それ以上には大きな ら声，精子の数が增加し凝集して最終的に金属状に近い銀になる もの上考无ら扎る。膜在はがして測定した光照射面に対与る襄面

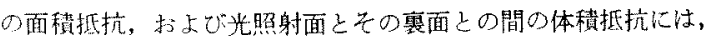
2 時關の紫外線照射では变化は見られない。このことは，光照射

4) E. Klein, H. J. Metz, phot. Sct. \& Eng. 5, 5(1961). 
による電導性物質の析出が薄膜の光照射面に片寄っているこ上荃 示している。曆さ約 $5 \mu$ のアルギン酸銀膜は，2時間の紫外線照 射でその䄪半分が光分解していることが分析の絬果明らか心な。 ている。また筆位体檟中の銀原子の数から計算したアルギン酸銀

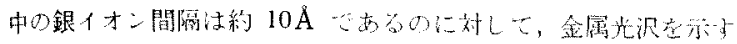

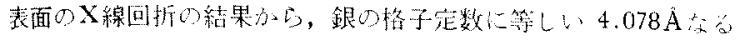

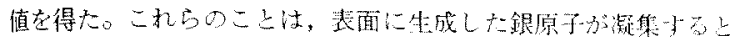

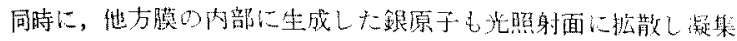
ナるものでること交示している。

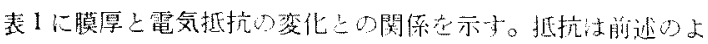

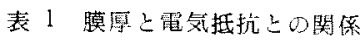

\begin{tabular}{|c|c|c|c|c|}
\hline 厚さ $(\mu)$ 照射時間 & 0 & 1 & 2 & 3 \\
\hline 1 & $3.65 \times 10^{9}$ & $1.0 \times 10^{11}$ & $6.6 \times 10^{8}$ & $5.5 \times 1$ \\
\hline 2.5 & $1.34 \times 10^{9}$ & $1.0 \times 10^{9}$ & $1.1 \times 10^{7}$ & $2.8 \times 10^{0}$ \\
\hline 5 & $6.3 \times 10^{8}$ & $1.9 \times 10^{6}$ & $3.6 \times 10^{2}$ & $0.82 \times 10^{2}$ \\
\hline 10 & $3.7 \times 10^{8}$ & $5.2 \times 10^{5}$ & $2.8 \times 10^{2}$ & $1.6 \times 10^{2}$ \\
\hline
\end{tabular}

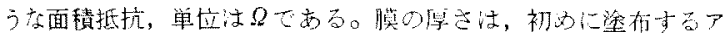
ルギン酸ナトリウム溶液の謴度を变えることによって变化てき

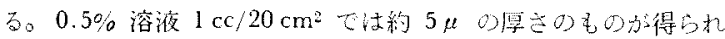
る。表1からすかるように，㫗さ1 $1 \mu$ および $2.5 \mu$ のアルギン 酸銀膜七は，3時間の紫外線照射こも大き電気抵抗の減少は見

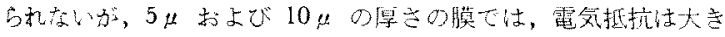
く隇少して䄪 $10^{2} \Omega$ の大きさになる。 $5 \mu$ の膜暻の場合，2時間 の紫外楾照射に上ってその約半分のアルギン酸銀が光分解し電気

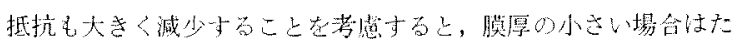

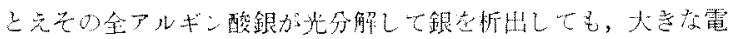

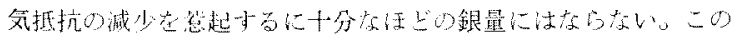

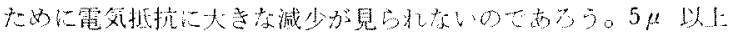

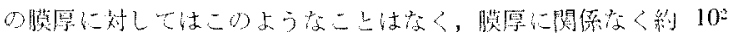
Qの值に走て隇少与。

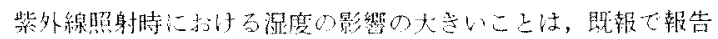

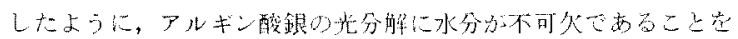

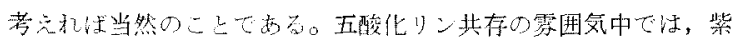

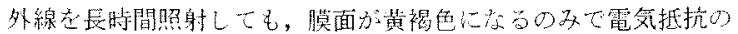

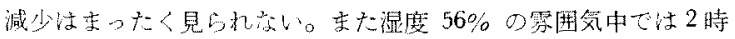
間の光照射約 $10^{6} \Omega$ になて抵抗の減少が見られる程度である。

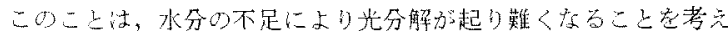
礼壮当然すす。

この報告てはアルギン酸銀膜についてのみ報告したが，他の高

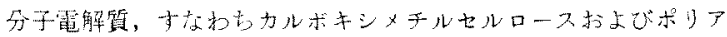

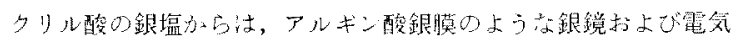

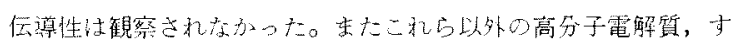

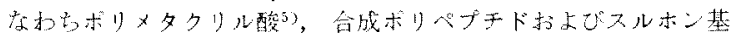
花持った高分子電解質策どについても，アルギン酸銀膜に数似し

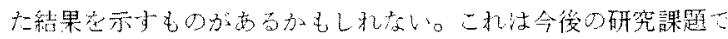
ある。

本論文を終えるにあたり，装置などの援助をいただいた富士写 真つイル山株式会社に骼謝の意謷する。

(1964 年4月，日本化学会第 17 年会発表)

5) J. Kubal, Nalure 183, 1175(1962).

\title{
加硫天然ゴムの応力緩和と赤外二色性変化の同時測定
}

\author{
(昭和 40 年 8 月 9 日受理)
}

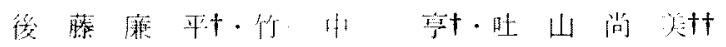

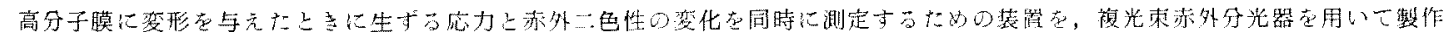

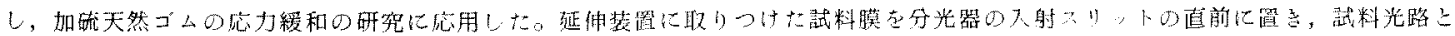

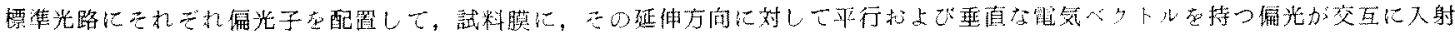

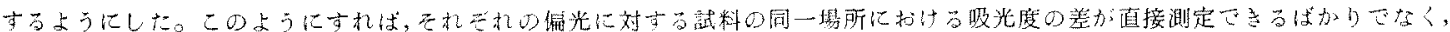

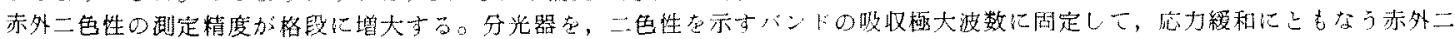

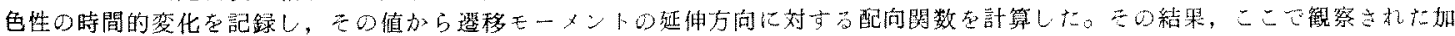

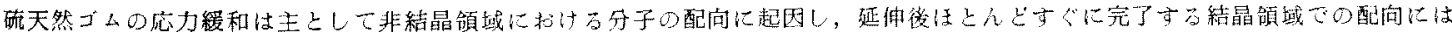
あまり関保しないことを推論した。

\section{1 緒 言}

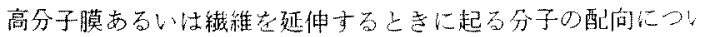

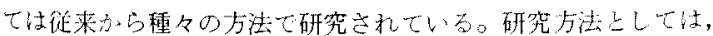

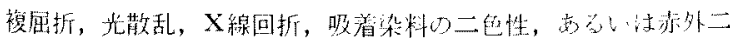
色性などが用いられる。この中て，赤外三甶性による方法は，高 分子鎖や結晶部分の配向性を知ることがでるのみならず，個々

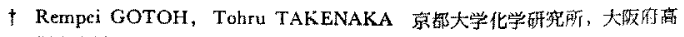
柣南大学町

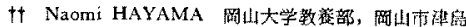

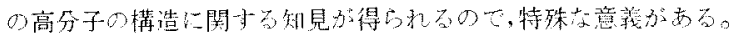

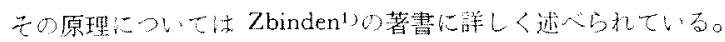

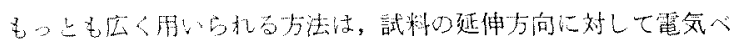

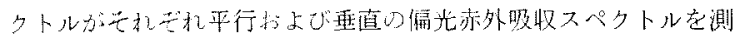

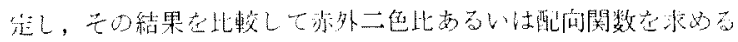
のと古って，主乞して平衡状態にある試料について研究夲行なっ イニものダ多く, 試料の浆形過程に閶するものは比較的少ない。最

1) R. Zbinden, "Infrared Spectroscopy of High Polymers" Academi Press, New York(1964)chap. V. 